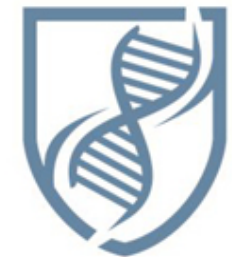

Journal of Bioscience and Applied Research
JBAAR

WWW.JBAAR.ORG

\title{
Potential role of probiotic bacteria as antioxidants agent
}

\author{
Mostafa El-Sheekh ${ }^{1}$, Nanis G. Allam ${ }^{1}$, Naglaa Ibrahim Sarhan ${ }^{2}$ and Ghada Alfakharany ${ }^{1}$ \\ Botany Department, Faculty of Science, Tanta University, 31527 Tanta, \\ Egypt $^{1}$ Histology Department, Faculty of Medicine, Tanta University, Egypt ${ }^{2}$ \\ (Corresponding author email: nallam991@gmail.com)
}

\begin{abstract}
Oxidants are free radicals that find in the environment, but they are also produced naturally in our body. Antioxidants have an important role in the body health and protected from many diseases caused by free radicals. The unique characters of probiotic bacteria make it used extensively in the field of medicine antioxidant, anticancer, anti-microbial, anti-diabetic, antiinflammatory properties and hepatoprotective agent. This study was designed to explore the influence of lactic acid bacteria as antioxidative agents. Antioxidative properties for all tested stains were investigated through determination scavenging activity of $\alpha, \alpha$-Diphenyl- $\beta$ Picrylhydrazyl (DPPH), hydroxyl radicals $\left(\mathrm{OH}^{-}\right)$and inhibition of lipid peroxidation in rat liver homogenate in vitro. The present findings revealed that, Lactobacillus plantarum subsp. plantarum DSMZ 20174 and Lactobacillus acidophilus DSMZ 20079 T possessed the highest antioxidant properties, tolerated acidity up to 4 and revealed viability under bile salt concentration up to $0.5 \%$. The results of this study provide new insights into the lactic acid bacteria with antioxidative properties as they tolerated acidity up to and revealed viability under bile salt concentration .
\end{abstract}

Keywords: antioxidant activity, lactic acid bacteria, acid and bile tolerance.

\section{Introduction}

Oxidative stress occurs when there is an imbalance between reactive oxygen species (ROS) formation and scavenging by antioxidants. Excess generation of ROS can cause oxidative damage to biomolecules resulting in lipid peroxidation, mutagenesis and carcinogenesis (Khan and Sultana, 2009).

Probiotics are live microorganisms thought to be beneficial to the host organism. According to the currently adopted definition by FAO/WHO, probiotics are: "Live microorganisms which when administered in adequate amounts confer a health benefit on the host". Lactic acid bacteria (LAB) and bifidobacteria are the most common types of microbes used as probiotics; but certain yeasts and bacilli may also be helpful. Lactic acid bacteria (LAB), which are widely used in the food industry, are generally recognized as safe (Liu and Pan 2010). LAB, particularly lactobacilli, has recently received increasing attention because of their specific role in maintaining human health and in decreasing the risk of ROS accumulation (Choi et al., 2006) and (Lee et al., 2005).

Lactic acid bacteria have various potential biological functions (De Vrese, and Schrezenmeir, 2008). Several studies have provided evidence that certain lactic acid bacteria possess antioxidative activity (Mikelsaar and Zilmer, 2009). Saide and Gilliland, (2005) suggested that some Lactobacilli strains are a source of dietary antioxidants. In our previous studies, we also demonstrated that lactic acid bacteria possess antioxidative ability through one or multiple mechanisms, including metal ion chelation, radical scavenging, inhibition of lipid peroxidation and activity reduction in vitro (Lin and Chang, 2000). The present study attempt to evaluate the antioxidant activity of different probiotic bacteria. 


\section{Materials and Methods}

\section{Bacterial strains and culture}

Lactobacillus plantarum subsp. plantarum DSMZ 20174, Bifidobacterium bifidum, lactobacillus rhamnosus ATCC 7469, Bifidobacterium longum subsp. longum DSMZ 200707, Streptococcus lactis subsp. cremoris, Lactobacillus rhamnosus, Lactobacillus reuteri, Lactobacillus casei, Lactobacillus delbrueckii subsp.bulgaricus, Lactobacillus delbrueckii subsp. bulgaricus DSMZ 20080. Streptococcus thermophilus, Lactobacillus acidophilus DSMZ 20079 T and, Lactobacillus fermentum DSMZ 20049, were kindly provided from microbiological recourses center (Cairo MIRCEN), Faculty of Agriculture Ain Shams University, Faculty of Agriculture Kafr El-Sheikh University and Faculty of Science Tanta University. All strains were cultured in De Man-Rogosa- Sharpe (MRS) broth at $37^{\circ} \mathrm{C}$ for $24 \mathrm{~h}$.

\section{Effect of bile salts and pH on bacterial growth.}

\section{Bile tolerance}

Bile tolerance of all the investigated strains were studied described by Gilliland et al., (1984). Briefly, MRS broth supplemented with different concentrations of bile salts ( 0.3 and $0.5 \%$ ox-bile salts, Oxoid) was inoculated with $1 \%$ inoculums $\left(1 \times 10^{9} \mathrm{CFU}\right)$ and incubated at $37^{\circ} \mathrm{C}$ for $1 \mathrm{~h}$, then samples were drawn, plated on MRS plates and incubated at $37^{\circ} \mathrm{C}$ for $24 \mathrm{~h}$. Growth on the plates indicated their tolerance to bile salts. The control comprised of MRS without bile salt.

\section{Acid tolerance}

MRS with different $\mathrm{pH}$ (2.0, 3.0, and 4.0 adjusted with $\mathrm{HCl})$ was prepared according to Pereira and Gibson (2002). Then was inoculated with $1 \%$ inoculums $\left(1 \times 10^{9}\right.$ CFU) and incubated grown overnight. Samples were drawn, plated on MRS plates and incubated at $37^{\circ} \mathrm{C}$ for 24h.

\section{Antioxidant activities of the probiotic} bacterial strains

\section{Hydroxyl radical scavenging capacity of the probiotic bacteria:}

Hydroxyl radical $\left(\mathrm{OH}^{-}\right)$scavenging assay was performed according to Wang et al., (2008). $\mathrm{OH}^{-}$was generated by Fenton reaction in the system of $\mathrm{FeSO}_{4}$ and $\mathrm{H}_{2} \mathrm{O}_{2}$. The reaction mixture was consisted of $0.5 \mathrm{ml}$ $\mathrm{FeSO}_{4}(8 \mathrm{mM}), 0.8 \mathrm{ml} \mathrm{H} \mathrm{O}_{2}(6 \mathrm{mM})$, and $0.5 \mathrm{ml}$ distilled water. $1.0 \mathrm{ml}$ of each of the bacterial treatments and 0.2 $\mathrm{ml}$ sodium salicylate $(20 \mathrm{mM})$ were added and incubated at $37{ }^{\circ} \mathrm{C}$ for $1 \mathrm{~h}$. The absorbance of the mixture was recorded at $562 \mathrm{~nm}$. The scavenging activity was calculated using the following Equation:
Scavenging or inhibition rate $\%=[1-(\mathrm{A} 1$ A2)/A0] $\times 100$

Where: A0 is the absorbance of the control (without sample), A1 is the absorbance of the sample addition, A2 is the absorbance without sodium salicylate.

Determination of 2-2,2-diphenyl-picrylhydrazyl (DPPH) radical scavenging activity of the probiotic bacteria

The capacity of the probiotic bacterial treatments to reduce the 2, 2-diphenyl-picrylhydrazyl (DPPH) stable free radical was assessed using the method described by Blois (2002). DPPH (2, 2 diphenyl-1-picrylhydrazyl): $(0.025 \mathrm{~g} / \mathrm{L}) 0.025 \mathrm{~g}$ was dissolved in 1 liter methanol. Added $0.1 \mathrm{ml}$ of sample extract (after 24, 48, 72 and $96 \mathrm{~h}$ incubation) to $3.9 \mathrm{ml}$ of DPPH solution. Total mixture was incubated at room temperature for $30 \mathrm{~min}$ in the dark conditions. The absorbance was recorded at $515 \mathrm{~nm}$ Hsu et al., (2006). The percentage of DPPH scavenging activity was calculated according to absorbance difference as has been depicted in equation:

DPPH scavenging \% = [1 - (A1 -A2)/A0 $] \times 100$

Where, A0 is the absorbance of DPPH alone. A1 is the absorbance of DPPH + sample. A2 is the absorbance of the sample only.

Inhibition of lipid peroxidation in rat liver homogenate by the probiotic bacterial strains

The inhibition effect on lipid peroxidation was determined according to the thiobarbituric acid method with some modifications Chu-Chyn et al., (2009); $\mathrm{FeCl}_{2}-$ $\mathrm{H}_{2} \mathrm{O}_{2}$ was used to induce the liver homogenate peroxidation. In this method, One millilitre of liver homogenate (each $100 \mathrm{ml}$ homogenate solution contains $1.0 \mathrm{~g}$ rat liver), $100 \mu \mathrm{L}$ PBS buffer, $1 \mathrm{mM} \mathrm{FeCl3,} 200 \mu \mathrm{L}$ ascorbic acid and cell-free extracts of probiotic bacterial strains were mixed. The mixture was incubated at $370 \mathrm{C}$ for $60 \mathrm{~min}$. The inhibition effect on lipid peroxidation was determined according to thiobarbituric acid assay described by Buege and Aust, (1978). The percentage of inhibition effect was calculated according to Eq. (3):

\section{The level of inhibition (\%) on lipid peroxidation= [A1- A2/A0] × 100\%}

Where: A0 is the absorbance of the control (without sample), A1 is the absorbance of the sample addition. A2 is the absorbance without liver homogenate.

\section{Results}

\section{Effect of bile salt and pH on growth of probiotic strains}

The initial $\mathrm{pH}$ of growth medium were adjusted to various $\mathrm{pH}$ values ranging from 2.0 to 4.0 using $\mathrm{HCl}$. Results of probiotic strains growth are recorded in Table (1). From the results, it could be noticed that the growth activity was increased with increasing in $\mathrm{pH}$ value. The maximum growth for all investigated strains was $\begin{array}{lll}\text { recorded } & \text { at } & \mathrm{pH}\end{array}$ 
Instead, the tested levels of bile salts did not influence growth or strain survival. There was no difference in cell yield between control cultures and those with bile.

\section{Hydroxyl radical scavenging capacity of probiotic \\ bacterial strains:}

The ability of probiotic bacterial strains to scavenge hydroxyl radicals was illustrated in Figure (1) and the results indicated that, there were huge varieties in the scavenging ability among the investigated bacteria. The scavenging capacity could be divided into three groups, week scavenging ability, obtained with cell free supernatant of Lactobacillus rhamnosus, Lactobacillus reuteri and Lactobacillus rhamnosus ATCC 7469 recorded inhibition percentages 40, 42 and 45\%, respectively. Moderate scavenging ability, obtained with supernatant of Lactobacillus delbrueckii subsp. bulgaricus DSMZ 20080, Streptococcus thermophilus, Lactobacillus delbrueckii subsp.bulgaricus, Lactobacillus fermentum DSMZ 20049, Lactobacillus casei, Streptococcus lactis subsp. cremoris and Bifidobacterium longum subsp. longum DSMZ 200707 with inhibition percentages 50, 55, 60, 65, 70, 70 and 75\% respectively. The excellent scavenging ability was obtained with the cell free supernatant of Bifidobacterium Bifidum, Lactobacillus acidophilus DSMZ 20079 and Lactobacillus plantarum subsp. plantarum DSMZ 2017 recorded inhibition percentages 77,78 and $90 \%$, respectively.

Table (1): Effect of bile salt and pH on growth of probiotic strains

\begin{tabular}{|c|c|c|c|c|c|}
\hline \multirow{2}{*}{ Bacterial Strains } & \multicolumn{2}{|c|}{ pH } & \multicolumn{2}{c|}{$\begin{array}{c}\text { Bile salt } \\
(\%)\end{array}$} \\
\hline & 2 & 3 & 4 & 0.3 & 0.5 \\
\hline Bifidobacterium Bifidum & - & + & + & + & + \\
\hline $\begin{array}{c}\text { Lactobacillus rhamnosus ATCC } \\
\text { 7469 }\end{array}$ & - & - & + & + & + \\
\hline $\begin{array}{c}\text { Lactobacillus reuteri } \\
\text { Lactobacillus plantarum subsp. } \\
\text { plantarum DSMZ 20174 }\end{array}$ & - & - & + & + & + \\
\hline $\begin{array}{c}\text { Bifidobacterium longum subsp. } \\
\text { longum DSMZ 200707 }\end{array}$ & - & - & + & + & + \\
\hline $\begin{array}{c}\text { Streptococcus lactis subsp. } \\
\text { cremoris }\end{array}$ & - & + & + & + & + \\
\hline Lactobacillus rhamnosus & - & - & + & \pm & \pm \\
\hline Lactobacillus casei & - & - & + & + & + \\
\hline Streptococcus thermophilus & - & - & + & + & + \\
\hline $\begin{array}{c}\text { Lactobacillus delbrueckii } \\
\text { subsp.bulgaricus }\end{array}$ & - & - & + & \pm & \pm \\
\hline $\begin{array}{c}\text { Lactobacillus delbrueckii subsp. } \\
\text { bulgaricus DSMZ 20080 }\end{array}$ & - & - & + & + & + \\
\hline $\begin{array}{c}\text { Lactobacillus acidophilus } \\
\text { DSMZ 20079 T }\end{array}$ & - & - & + & + & + \\
\hline Lactobacillus fermentum DSMZ & - & - & + & + & \pm \\
\hline
\end{tabular}

Note: -, no growth; \pm 50-70\% and $+>70 \%$ of control, respectively.

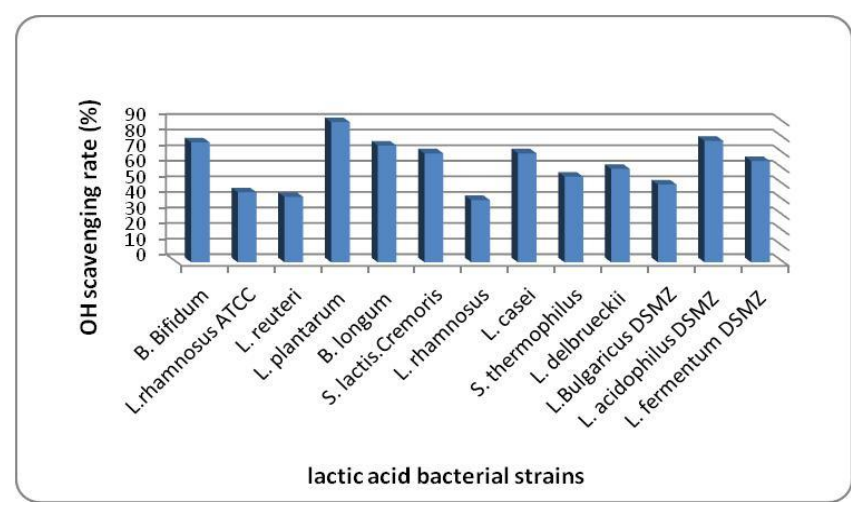

Figure (1): Hydroxyl radical scavenging capacity of probiotic bacterial strains

\section{Inhibition of lipid peroxidation in rat liver homogenate by LAB strains}

As shown in Table (2) the concluded data revealed that, among all treatments, the supernatant of Lactobacillus plantarum subsp. plantarum DSMZ 20174 and Lactobacillus acidophilus DSMZ $20079 \mathrm{~T}$ were superior as lipid peroxidation inhibitor than the other supernatants. Theses supernatants reported inhibition percentages reached 78.5 and 77.5 , respectively with MDA concentrations 1.67 and $1.65 \mu \mathrm{M} / \mathrm{ml}$, respectively, without significant differences between them.

\section{DPPH radical scavenging:}

DPPH radical scavenging activity of lactic acid bacterial supernatant was assayed after 24, 48, 72 and 96 $\mathrm{h}$ of incubation periods as shown in Table (3). At the end of incubation, the higher activity was recorded with the supernatants of both Lactobacillus plantarum subsp. plantarum DSMZ 20174 and Lactobacillus acidophilus DSMZ $20079 \mathrm{~T}$ with percentages of $90.4 \%$ and $92.0 \%$, respectively. Out of all represented data, the supernatant of lactobacillus rhamnosus ATCC 7469 showed the lowest scavenging percentage with value $62.35 \%$.

\section{Discussion}

The production of free radicals was related to many diseases (Devasagayam et al., 2004). Lactic acid bacteria, which have been traditionally used in the production of various fermented foods, are important intestinal microflora and natural antioxidants (Ou et al., 2012). Lactic acid bacteria considered as a bioactive safe microorganisms that normally transit the gastrointestinal tract and colonized intestinal microbial ecosystem promoting host health (Chu-Chynet et al., 2009). 
Table (2) Inhibition of lipid peroxidation in rat liver homogenate by the probiotic bacterial strains

\begin{tabular}{|c|c|c|}
\hline Strains & $\begin{array}{c}\text { MDA } \\
\text { concentration } \\
(\mu \mathrm{M} / \mathrm{ml})\end{array}$ & $\begin{array}{c}\text { Inhibition of } \\
\text { lipid } \\
\text { peroxidation \% }\end{array}$ \\
\hline & \multicolumn{2}{|c|}{ Bacterial supernatant } \\
\hline Lactobacillus reuteri & 2.11 & 62 \\
\hline $\begin{array}{c}\text { Lactobacillus rhamnosus } \\
\text { ATCC } 7469\end{array}$ & 1.78 & 70 \\
\hline Bifidobacterium Bifidum & 2.30 & 50 \\
\hline $\begin{array}{c}\text { Streptococcus lactis } \\
\text { subsp. cremoris }\end{array}$ & 1.74 & 72.5 \\
\hline $\begin{array}{c}\text { Bifidobacterium longum } \\
\text { subsp. longum DSMZ } \\
200707\end{array}$ & 2.10 & 65.5 \\
\hline $\begin{array}{c}\text { Lactobacillus plantarum } \\
\text { subsp. plantarum DSMZ } \\
20174\end{array}$ & 1.67 & 78.5 \\
\hline Lactobacillus rhamnosus & 1.72 & 75 \\
\hline Lactobacillus casei & 1.77 & 70 \\
\hline $\begin{array}{c}\text { Lactobacillus acidophilus } \\
\text { DSMZ } 20079 \mathrm{~T}\end{array}$ & 1.65 & 77.5 \\
\hline $\begin{array}{c}\text { Lactobacillus fermentum } \\
\text { DSMZ } 20049\end{array}$ & 1.77 & 70 \\
\hline $\begin{array}{c}\text { Lactobacillus delbrueckii } \\
\text { subsp. bulgaricus DSMZ } \\
20080 \\
\end{array}$ & 1.70 & 76 \\
\hline $\begin{array}{l}\text { Streptococcus } \\
\text { thermophilus }\end{array}$ & 1.77 & 70 \\
\hline $\begin{array}{c}\text { Lactobacillus delbrueckii } \\
\text { subsp.bulgaricus }\end{array}$ & 1.75 & 71 \\
\hline
\end{tabular}

The aim of the study was to show the possibility of using probiotic bacteria as natural free scavenging radical during many diseases, to achieve that hypothesis; the ability of bacteria to withstand bile salts and acidity were recorded. In the present study the effect of bile salt and $\mathrm{pH}$ on growth of probiotic strains showed that the growth activity was increased with increasing in $\mathrm{pH}$ value and reached its maximum value at $\mathrm{pH} 4$ with no bile salt it. There was no difference in cell yield between control cultures and those with bile salt. These results indicated that the investigated probiotic strains were tolerant to acidic conditions and provided beneficial aspects as they can be survival during passage to human stomach, digestive system and colonize the human gut. These results were in accordance with Shukla et al., (2010) who observed that some probiotic strains were more tolerant to acidic conditions than others either due to high cytoplasmic buffering capacity ( $\mathrm{pH}$ 3.72-7.74) or membrane ATPases that in turn may resist changes in cytoplasmic $\mathrm{pH}$ and gain stability under acidic conditions (Ritus et al., 1994). Also, they found that all the isolated strains were survived and tolerated bile salts (0.3\%) quite effectively.
Table (3) DPPH radical scavenging activity of the probiotic bacterial strains

\begin{tabular}{|c|c|c|c|c|}
\hline \multirow[t]{2}{*}{ Strain } & \multicolumn{4}{|c|}{$\begin{array}{l}\text { DPPH scavenging rate (\%) } \\
\text { Incubation time (hr.) }\end{array}$} \\
\hline & 24 & 48 & 72 & 96 \\
\hline $\begin{array}{c}\text { Lactobacillus } \\
\text { rhamnosus } \\
\text { ATCC } 7469\end{array}$ & 86.6 & 87.3 & 62.35 & 88.9 \\
\hline $\begin{array}{c}\text { Bifidobacterium } \\
\text { Bifidum }\end{array}$ & 85.6 & 86.1 & 83.4 & 85.6 \\
\hline $\begin{array}{c}\text { Bifidobacterium } \\
\text { longum subsp. } \\
\text { longum DSMZ } \\
200707\end{array}$ & 88.7 & 86.5 & 82.4 & 85.6 \\
\hline $\begin{array}{l}\text { Lactobacillus } \\
\text { plantarum } \\
\text { subsp. } \\
\text { plantarum } \\
\text { DSMZ 20174 } \\
\end{array}$ & 90.4 & 87.6 & 87.6 & 86.7 \\
\hline $\begin{array}{l}\text { Lactobacillus } \\
\text { reuteri }\end{array}$ & 88.9 & 87.1 & 90 & 88.4 \\
\hline $\begin{array}{c}\text { Streptococcus } \\
\text { lactis subsp. } \\
\text { cremoris }\end{array}$ & 89.8 & 89.9 & 89.9 & 89.8 \\
\hline $\begin{array}{l}\text { Streptococcus } \\
\text { thermophilus }\end{array}$ & 87.1 & 89.3 & 87.5 & 86.3 \\
\hline $\begin{array}{c}\text { Lactobacillus } \\
\text { casei }\end{array}$ & 89.7 & 86.3 & 84.1 & 84.4 \\
\hline $\begin{array}{l}\text { Lactobacillus } \\
\text { rhamnosus }\end{array}$ & 82.4 & 89.8 & 91.5 & 89.6 \\
\hline $\begin{array}{c}\text { Lactobacillus } \\
\text { delbrueckii } \\
\text { subsp.bulgaricus }\end{array}$ & 84.4 & 84.9 & 89.3 & 84.0 \\
\hline $\begin{array}{c}\text { Lactobacillus } \\
\text { acidophilus } \\
\text { DSMZ 20079 T } \\
\end{array}$ & 83.3 & 92.0 & 89.2 & 82.4 \\
\hline $\begin{array}{c}\text { Lactobacillus } \\
\text { delbrueckii } \\
\text { subsp. } \\
\text { Bulgaricus } \\
\text { DSMZ } 20080\end{array}$ & 90.8 & 87.6 & 90.2 & 91.1 \\
\hline $\begin{array}{l}\text { Lactobacillus } \\
\text { fermentum } \\
\text { DSMZ } 20049\end{array}$ & 89.1 & 87.5 & 86.8 & 87.9 \\
\hline
\end{tabular}

Note: DPPH Abso B=0.813 
On the other hand, the same results were obtained by Cenci et al., (2002) who observed that lactic acid bacteria isolated from commercial dairy products were tolerance to bile salt $(0.5 \%)$ and acid environment ( $\mathrm{pH} 2.0)$.

The antioxidative ability might be one of the main mechanisms for probiotic bacteria to prevention or treatment many diseases. Therefore, the hydroxyl radicals, DPPH scavenging and lipid peroxidation inhibition were tested in the present study to investigate the antioxidative properties of the probiotic strains.

In the current study, the ability of probiotic bacterial strains to scavenge hydroxyl radicals was done depending on generation of $\mathrm{OH}^{-}$radicals from the reaction of $\mathrm{FeSO}_{4}$ and $\mathrm{H}_{2} \mathrm{O}_{2}$ with sodium salicylate. The excellent scavenging capacity was recorded with the supernatant of Bifidobacterium Bifidum, Lactobacillus acidophilus DSMZ 20079 and Lactobacillus plantarum subsp. plantarum DSMZ 2017 with inhibition percentages 77, 78 and 90\%, respectively. Also, DPPH radical scavenging activities and percentages of lipid peroxidation inhibition were ranged between $62.35 \%$ $92 \%$ and $50 \%$ to $78.5 \%$ respectively. MDA is an end product of lipid peroxidation, and is considered a late biomarker of oxidative stress and cellular damage, and lipid peroxidation is one of the main manifestations of oxidative damage and it has been found to play an important role in the toxicity and carcinogenicity (Carampin et al., 2003). Furthermore, the increase of MDA has been considered a key feature in liver injury (Mateos et al., 2005). Oxidative stress arises when the generation of ROS, by-products of the oxidative metabolism primarily produced in the mitochondria, exceeds the cellular ability to eliminate them and to repair cellular damage, thus leading to oxidation of biomolecules including DNA, lipids and proteins (Hwang and Kim 2007). A similar finding has been reported by Ejtahed et al., (2012) that probiotic yogurt possessed markedly significantly decreased serum malondialdehyde concentration. Zhang and Zhang (2013) showed that many Lactobacillus strains with antioxidative effects were not only reducing MDA level, but also enhance the antioxidants production. Based upon, the free radical scavenging ability of lactic acid bacterial strains were significantly differ in scavenging ability according to bacterial strains. Lactobacillus plantarum DSMZ 20174 and Lactobacillus acidophilus DSMZ 20079 T revealed the highest antioxidant activity.

In conclusion, the antioxidative capacity evaluated for thirteen lactic acid bacteria strains in this study to select novel probiotics as antioxidant agent. The results revealed that the investigated lactic acid bacterial strains showed high tolerance against acidity, bile salt and have variable antioxidative activities. Lactobacillus plantarum DSMZ 20174 and Lactobacillus acidophilus DSMZ $20079 \mathrm{~T}$ were possessed the most antioxidant properties among other strains. Therefore Lactic acid bacteria especially Lactobacillus plantarum DSMZ 20174 and Lactobacillus acidophilus DSMZ 20079 T could be used as a supplementary ingredient to provide a dietary strategy in the treatment and prevention of many diseases.

\section{References}

Buege, J.A. Aust, S.D. (1978). Microsomal lipid peroxidation methods. Enzymol. 52: 302 - 310.

Carampin P, Rosan S, Dalzoppo D, Zagotto G, Zatta P (2003). Some biochemical properties of melatonin and the characterization of a relevant metabolite arising from its interaction with $\mathrm{H} 2 \mathrm{O} 2$. J Pineal Res 34:134-142

Cenci, Giovanni Rossi, Jone Trotta, Francesca Caldini, Giovanna (2002). Lactic acid bacteria isolated from dairy products inhibit genotoxic effect of 4nitroquinoline-1-oxide in SOS-chromotest. Systematic and applied microbiology. 25(4). 483-490.

Choi SS, Kim Y, Han KS, You S, Oh S, Kim SH (2006). Effects of Lactobacillus strains on cancer cell proliferation and oxidative stress in vitro. Lett Appl Microbiol.; 42: 452-458.

Chu-Chyn Ou, Tsong-Ming Lu, Jaw-Ji Tsai, JyhHerng Yen, Haw-Wen Chen and Meei-Yn Lin. (2009). Antioxidative Effect of Lactic Acid Bacteria: Intact Cells vs. Intracellular Extracts. J.Food and Drug Analysis, 17(3): 209-216.

De Vrese, M. and Schrezenmeir, J. (2008). Probiotics, prebiotics, and synbiotics. Adv. Biochem. Eng. Biotechnol. 111: 1-66.

Devasagayam, T.P.A., Tilak, J.C., Boloor, K.K., Sane, K.S., Ghaskadbi, S.S., Lele, R.D., (2004). Free radicals and antioxidants in human health: current status and future prospects. Journal of Association of Physicians of India 52, 794-804

Ejtahed HS, Mohtadi-Nia J, Homayouni-Rad A, et al, (2012). Probiotic yogurt improves antioxidant status in type 2 diabetic patients.Nutrition; 28(5) 539-543.

Gilliland, S.E, Staley, T.E., and Bush, L.J. (1984). Importance of bile tolerance of Lactobacillus acidophilus used as dietary adjunct. J. Dairy Sci. 67: 3045-3051.

Hsu, H. W. Vavak, D. L. Satterlee, L. D.; Miller, G. A., (2006). A multienzyme technique for estimating protein digestibility. J. Food Sci., 42 (5): 1269-1273.

Hwang ES, Kim GH (2007). Biomarkers for oxidative stress status of DNA, lipids, and proteins in vitro and in vivo cancer research. Toxicology 229: 1-10.

Khan, T. and Sultana, S. (2009). Antioxidant and hepatoprotective potential of Aegle marmelos Correa against CCl4-induced oxidative stress and early tumor events. Journal of Enzyme Inhibition and Medicinal Chemistry, 24 (2): 320-7.

Lee J, Hwang KT, Heo MS, Lee JH, Park KY (2005). Resistance of Lactobacillus plantarum KCTC 3099 from Kimchi to oxidative stress. J Med Food. 8: 299-304.

Lin, M.Y., Chang, F.Y., 2000. Antioxidative effect of intestinal bacteria Bifidobacterium longum ATCC 
15708 and Lactobacil- lus acidophilus ATCC 4356. Dig. Dis. Sci. 45, 1617-1622.

Liu C, Pan T (2010). In Vitro Effects of Lactic Acid Bacteria on Cancer Cell Viability and Antioxidant Activity. J Food Drug Anal. 18: 77-86.

Mikelsaar, M. and Zilmer, M. 2009. Lactobacillus fermentum ME-3 - an antimicrobial and antioxidative probiotic. Microb. Ecol. Health. Dis. 21: 1-27.

Ou, Chu-chyn Chiu, Yi-heng Lin, Shiao-lin Chang, Ya-ju Huang, Hsin-yu Lin, Meei-yn (2012). Hepatoprotective Effect of Lactic Acid Bacteria in the Attenuation of Oxidative Stress from tert -Butyl Hydroperoxide. Journal of Food and Drug Analysis. 20(1). 101-110.

Pereira, D. I. A. and Gibson, G. R. (2002). Cholesterol assimilation by lactic acid bacteria and Bifidobacteria isolated from the human gut. Appl. and Environ. Microbiol. 68, (9) 4689-4693.

Ritus N.; Sole M.; Francis A.; Loren JG, (1994). Buffering capacity and membrane $\mathrm{H}+$ conductance of lactic acid bacteria, FEMS Microbiol Lett, 120, 291-296.
Saide, J. A. and Gilliland, S. E. (2005). Antioxidative activity of lactobacilli measured by oxygen radical absorbance capacity. J. Dairy Sci. 88: 1352-1357.

Shukla, Geeta Sharma, Gatha Goyal, Nisha (2010). Probiotic Characterization of Lactobacilli and Yeast Strains Isolated from Whey Beverage and Therapeutic Potential of Lactobacillus Yoghurt in Murine Giardiasis. American Journal of Biomedical Sciences. 2(3), 248-261.

Wang H., Gao X.D., Zhou G.C., Cai L., Yao W.B (2008). In vitro and in vivo antioxidant activity of aqueous extract from Choerospondias axillaris fruit. Food Chem.; 106:888-895.

Zhang, Y. Zhang, H. (2013). The Effect of Probiotics on Lipid Metabolism, Lipid Metabolism, Prof. Rodrigo Valenzuela Baez (Ed.), InTech, DOI:10.5772/51938. Available from: http://www.intechopen.com/books/lipid-metabolism/theeffect-of-probiotics-on-lipid-metabolism 